\title{
Wpływ pracy zawodowej na występowanie zespołów bólowych kręgosłupa na przykładzie pielęgniarek pracujących w oddziałach szpitalnych
}

\author{
Influence of professional work on the occurrence of back pain \\ syndromes on the example of nurses working in hospital departments
}

\author{
JUSTYNA TERPIŁOWSKA ${ }^{1}$ \\ 1 Powiatowy Szpital w Aleksandrowie Kujawskim, Oddział Intensywnej Terapii \\ http://dx.doi.org/10.21784/IwP.2021.002
}

\section{Streszczenie}

Wstęp. Zespoły bólowe kręgosłupa są schorzeniem, które dotyka osób w coraz młodszym wieku. Na występowanie tej dolegliwości ma wpływ wiele czynników, takich jak: wiek, płeć, predyspozycje genetyczne, styl życia oraz rodzaj i staż wykonywanej pracy. Personel pielęgniarski jest grupą szczególnie narażoną na dolegliwościami ze strony układu mięśniowo-szkieletowego ze względu na czynności wykonywane w pracy zawodowej. Jest to m.in. dźwiganie pacjentów, sprzętu medycznego, pokonywanie barier architektonicznych, przenoszenie, podnoszenie, praca w wymuszonej pozycji, długotrwałe stanie, chodzenie lub siedzenie.

Cel. Celem pracy było określenie wpływu pracy zawodowej na występowanie zespołów bólowych kręgosłupa w grupie pielęgniarek pracujących w oddziałach szpitalnych.

Materiał i metody. W pracy została zastosowana metoda sondażu diagnostycznego. Techniką badawczą było ankietowanie. Narzędzia użyte w pracy to autorski kwestionariusz ankiety.

Wyniki. W przeprowadzonym badaniu wszyscy respondenci (100\%) doświadczają zespołów bólowych kręgosłupa. Zdecydowana większość (84\%) wskazuje, że jest to ból w okolicy lędźwiowej. 
Wnioski. Zespoły bólowe kręgosłupa w grupie badanych istotnie różnią się w zależności od takich zmiennych socjodemograficznych jak: wiek, staż pracy, wykształcenie, miejsce zamieszkania. Podejmowanie działań przez badanych w zakresie profilaktyki zespołów bólowych kręgosłupa istotnie różni się w zależności od zmiennych socjodemograficznych takich jak: wykształcenie oraz miejsce zamieszkania.

Słowa kluczowe: pielęgniarka, zespoły bólowe, kręgosłup, praca

\section{Summary}

Introduction. Back pain syndromes are a disease that affects people at an increasingly younger age. On factors that affect many, such as: age, gender, genetic predisposition, life systems, and the type and length of work. The caregiver is a dangerous personnel who may expose us to the musculoskeletal side due to the activity of the work activities. Exactly to, among others lifting people, technical equipment, architectural overcoming, carrying, lifting, forced position work, long-term maintenance, walking or sitting.

Objective of the work. The aim of the study was to determine the influence of professional work of back pain syndromes in the group of nurses working in hospital departments.

Material and methods. The paper uses the method of a diagnostic survey. The research technique was surveying. The tools used in the work are: the original questionnaire.

Results. In the survey, all respondents (100\%) experience back pain syndromes. However, the vast majority $(84 \%)$ indicate that it is pain in the lumbar region.

Conclusions. Back pain syndromes in the group of respondents differ significantly depending on such sociodemographic variables as: age, seniority, education, place of residence. Taking action by the respondents in the field of prophylaxis of back pain syndromes significantly differs depending on sociodemographic variables such as: education and place of residence.

Key words: nurse, pain syndromes, spine, work 


\section{Wstęp}

Zespoły bólowe kręgosłupa są poważnym problemem medycznym oraz ekonomiczno-społecznym. Jest to najczęstsza przyczyna absencji zawodowej oraz ograniczenia aktywności.

W skali globalnej stanowią jeden z głównych problemów dotyczących zdrowia publicznego $[1,2]$.

Według danych około 75-85\% populacji ogólnej chociażby raz w swoim życiu doświadcza incydentu bólowego dolnego odcinka kręgosłupa. Zaobserwowano, że dolegliwości w tym zakresie pojawiają się średnio u 60\%-80\% ludności powyżej 32 roku życia. Dane opublikowane przez Główny Urząd Statystyczny w 2014 r. sugerują, że zespoły bólowe kręgosłupa są najczęstszym problemem zdrowotnym wśród Polaków. Skarży się na nie co czwarta kobieta oraz średnio co piąty mężczyzna w wieku 30-39 lat [3, 4, 2].

Etiologia zespołów bólowych kręgosłupa jest wieloaspektowa. Najczęstszą przyczyną powstawania przeciążeń w tym obszarze jest oddziaływanie czynnika mechanicznego siłą przekraczającą próg adaptacyjny oraz wytrzymałość kręgosłupa [5]. Na rozwój schorzeń układu mięśniowo-szkieletowego wpływ mają także: siedzący tryb życia, nadwaga, aspekty genetyczne, stosowanie używek, przyjmowanie niefizjologicznej pozycji w trakcie wypoczynku, a także nieergonomicznej postawy podczas pracy zawodowej. Niestety, w dalszym ciągu świadomość społeczeństwa na temat mechanizmów przeciążeniowych jest mała $[1,6]$.

Objawem sugerującym zespoły bólowe kręgosłupa jest najczęściej silny ból, który przybiera różnego rodzaju nasilenie. Zdarza się, że ustępuje on samoczynnie podczas przyjmowania określonym pozycji ciała, bądź wykonywania określonych ruchów. Objawami, współistniejącymi z dolegliwościami bólowymi kręgosłupa jest bardzo często: drętwienie, mrowienie, zaburzenia czucia, osłabienie siły mięśniowej, odruchowe przyjmowanie nienaturalnej pozycji ciała, objawy ze strony jelit oraz pęcherza moczowego, a także rozdrażnienie [7].

Pielęgniarstwo jako profesja obarczone jest ryzykiem występowania zespołów bólowych kręgosłupa. Pielęgniarki w swojej pracy 
wykonują wiele czynności, które mogą bezpośrednio skutkować przeciążeniami układu mięśniowo-szkieletowego. Wiele z nich wykonuje się w przodopochyleniu od 30 sekund do 15 minut. Dane wskazują, że podczas 8 godzinnej zmiany są one w stanie przejść średnio od 4 do $7 \mathrm{~km}$. Wielokrotnie dźwigają, przenoszą chorych oraz sprzęt medyczny, pokonują bariery architektoniczne, schylają się, pracują w zmianowym systemie pracy. Dodatkowo wiele z tych czynności wykonują w nieergonomicznej pozycji ciała $[8,3,9]$.

\section{Cel}

Celem przeprowadzonych badań było określenie wpływu pracy zawodowej na występowanie zespołów bólowych kręgosłupa w grupie pielęgniarek pracujących w oddziałach szpitalnych.

\section{Materiał i metody}

Badaniami została objęta grupa 100 pielęgniarek i pielęgniarzy zatrudnionych w Szpitalu powiatowym w Aleksandrowie Kujawskim, powyżej 20 roku życia, którzy w różnej formie i różnym wymiarze godzin pozostają zatrudnieni $\mathrm{w}$ charakterze pielęgniarki/pielęgniarza oraz posiadają wykształcenie z zakresu pielęgniarstwa. Liczba kobiet wyniosła 98 osób tj. 98,0\%. Badanych podzielono na trzy grupy wiekowe: 24-39 lat, 40-54 lata oraz powyżej 55 lat. Najliczniejszą grupę tj. 60\% stanowiły osoby w wieku $40-54$ lata. Z kolei $29 \%$ badanych stanowiły osoby w wieku 24-39 lat. Najmniej liczną grupę osób (11\%) stanowili badani w wieku 55 i więcej lat. Najliczniejszą grupę stanowili badani po liceum medycznym tj. 43\%, bądź po studiach licencjackich z pielęgniarstwa (42\%). Najmniej liczni byli respondenci po studiach magisterskich z pielęgniarstwa - 6,0\%. Większość badanych zamieszkiwała wieś tj. 73,0\% . Pozostała część (27\%) zamieszkiwała miasto. Badani zostali podzieleni na trzy grupy stażu pracy: 1-10 lat, 11-25 lat, 26 i więcej lat. Najliczniejszą grupę stanowili badani ze stażem pracy 11-25 lat tj. 48\%. Najmniej liczną grupą byli respondenci ze stażem pracy 1-10 lat - 19\%. Grupa osób ze stażem pracy w przedziale 26 i więcej wyno- 
siła 33\%. Najwięcej badanych zatrudnionych było na umowę o pracę tj. $81 \%$. Najmniej na umowę kontraktową - 1\%. Z kolei 18\% zdeklarowało się, że pracuje na umowę zlecenie. Wszyscy badani wskazali, że pracują w systemie dwuzmianowym (12 h noc, dzień).

Respondenci wyrazili zgodę na udział w badaniach, a ich stan zdrowia nie stanowił przeszkody w samodzielnym wypełnianiu autorskiego kwestionariusza ankiety. Dotyczył on dolegliwości bólowych kręgosłupa, lokalizacji, profilaktyki, sposobu radzenia sobie z bólem oraz sytuacji nasilających ból. Zebrany materiał wprowadzono do arkuszu kalkulacyjnego programu Excel 2010. Wszystkie obliczenia wykonano za pomocą programu statystycznego Statistica 10.0 firmy StatSoft. Badania poddano analizie opisowej, graficznej oraz statystycznej. Przyjęto poziom istotności $p \leq 0,05$.

\section{Wyniki}

Wszyscy badani odpowiedzieli, że doświadczają dolegliwości bólowych kręgosłupa w różnych odstępach czasu (tabela 1).

Tabela 1. Częstość występowania dolegliwości bólowych kręgosłupa wśród badanych.

\begin{tabular}{|c|r|r|}
\hline $\begin{array}{c}\text { Częstość występowania } \\
\text { dolegliwości bólowych } \\
\text { kręgosłupa }\end{array}$ & $\mathbf{n}$ & $\mathbf{\%}$ \\
\hline codziennie & 27 & 27,0 \\
\hline raz w tygodniu & 36 & 36,0 \\
\hline kilka razy w miesiącu & 29 & 29,0 \\
\hline raz na pół roku & 7 & 7,0 \\
\hline raz na rok & 1 & 1,0 \\
\hline Ogółem & $\mathbf{1 0 0}$ & $\mathbf{1 0 0 , 0}$ \\
\hline
\end{tabular}

Źródło: opracowanie własne 
Najwięcej badanych wskazało, że dolegliwości bólowe kręgosłupa występują u nich raz w tygodniu - 36,0\%. Niewiele mniej, bo $29 \%$ stwierdziło, że ból występuje kilka razy w miesiącu. Natomiast $27 \%$ respondentów stwierdziło, że dolegliwości pojawiają się codziennie. Najmniejszy odsetek ankietowanych wskazał, że pojawiają się one raz na pół roku (7\%) oraz raz na rok (1\%).

W tabeli 2 przedstawiono odcinek kręgosłupa, który badani wskazali jako największa lokalizacja dolegliwości bólowych.

Tabela 2. Odcinek kręgosłupa, w którym występują największe dolegliwości bólowe.

\begin{tabular}{|c|c|c|}
\hline Lokalizacja & liczba & \% \\
\hline odcinek szyjny & 12 & 12,0 \\
\hline odcinek piersiowy & 2 & 2,0 \\
\hline odcinek lędźwiowy & 84 & 84,0 \\
\hline nie dotyczy & 2 & 2,0 \\
\hline Ogółem & $\mathbf{1 0 0}$ & $\mathbf{1 0 0 , 0}$ \\
\hline
\end{tabular}

Źródło: opracowanie własne

Najwięcej badanych wskazało, że największe dolegliwości bólowe kręgosłupa występują w odcinku lędźwiowym tj. 84,0\%. Natomiast $12 \%$ stwierdziło, że najbardziej bolesna lokalizacja to odcinek szyjny kręgosłupa. Najmniej, wskazało odcinek piersiowy, bądź że ich ten problem nie dotyczy - po $2 \%$.

W tabeli 3 przedstawiono wykonywane czynności przez badanych w największym zakresie nasilające dolegliwości bólowe kręgosłupa. 
Tabela 3. Wykonywane czynności przez badanych w największym zakresie nasilające dolegliwości bólowe kręgosłupa.

\begin{tabular}{|c|r|r|}
\hline Czynność & liczba & \multicolumn{1}{c|}{ \% } \\
\hline praca w pozycji stojącej & 8 & 8,0 \\
\hline dźwiganie & 55 & 55,0 \\
\hline praca w pozycji pochylonej & 34 & 34,0 \\
\hline pokonywanie dużych odległości & 3 & 3,0 \\
\hline siedzenie & 0 & 0,0 \\
\hline Ogółem & $\mathbf{1 0 0}$ & $\mathbf{1 0 0 , 0}$ \\
\hline
\end{tabular}

Źródło: opracowanie własne

Najwięcej respondentów tj. 55\% wskazało, że dźwiganie to czynność w największym zakresie nasilająca dolegliwości bólowe kręgosłupa Praca w pozycji pochylonej to następna najczęstsza odpowiedź wskazywana przez badanych- 34,0\%. Natomiast 8\% respondentów wskazało, że jest to praca w pozycji stojącej. Z kolei najmniej stwierdziło, że jest to pokonywanie dużych odległości - 3,0\%. Żaden z badanych nie wskazał, że siedzenie nasila ból.

W tabeli 4 przedstawiono staż pracy, po jakim wystąpiły dolegliwości bólowe kręgosłupa w określonych grupach wiekowych respondentów. W tym celu podzielono badanych na trzy grupy: 24-39 lat, 4054 lata, 55 i więcej lat.

Tabela 4. Okres stażu pracy po jakim wystąpiły dolegliwości bólowe kręgosłupa w grupach wiekowych badanych.

\begin{tabular}{|c|r|r|r|r|r|r|}
\hline Wiek & \multicolumn{2}{|c|}{$\mathbf{2 4 - 3 9}$ lat } & \multicolumn{2}{c|}{$\mathbf{4 0 - 5 4}$ lata } & \multicolumn{2}{c|}{ 55 i więcej lat } \\
\hline Staż & liczba & \multicolumn{1}{c|}{ \% } & liczba & \multicolumn{1}{c|}{$\%$} & liczba & \multicolumn{1}{c|}{$\%$} \\
\hline poniżej 5 lat & 25 & 86,2 & 37 & 61,7 & 2 & 18,2 \\
\hline 6-19 lat & 3 & 10,3 & 23 & 38,3 & 4 & 36,4 \\
\hline powyżej 25 lat & 0 & 0,0 & 0 & 0,0 & 5 & 45,5 \\
\hline nie wystąpiły & 1 & 3,4 & 0 & 0,0 & 0 & 0,0 \\
\hline Ogółem & $\mathbf{2 9}$ & $\mathbf{1 0 0 , 0}$ & $\mathbf{6 0}$ & $\mathbf{1 0 0 , 0}$ & $\mathbf{1 1}$ & $\mathbf{1 0 0 , 0}$ \\
\hline
\end{tabular}

Źródło: opracowanie własne 
Najwięcej badanych w wieku 24-39 lat wskazało, że dolegliwości bólowe kręgosłupa wystąpiły u nich już poniżej 5 lat stażu pracy tj. $86,2 \%$, najmniej natomiast stwierdziło, że nie wystąpiły u nich wcale 3,4\%. Najwięcej respondentów w wieku 40-54 lata wskazało, że ból pojawiał się już poniżej 5 lat stażu pracy $-61,7 \%$ a pozostali wskazali, że po 6-19 lat pracy - 38,3\%. Najwięcej badanych w wieku 55 i więcej lat podało, że dolegliwości wystąpiły powyżej 25 lat stażu pracy tj. 45,5\%, a najmniej, że poniżej 5 lat zatrudnienia $-18,2 \%$.

W tabeli 5 przedstawiono staż pracy badanych, po jakim wystąpiły dolegliwości bólowe kręgosłupa w grupach okresu zatrudnienia. W tym celu podzielono respondentów na 3 grupy w zależności od przepracowanego okresu czasu: 1-10 lat, 11-25 lat, 26 i więcej.

Tabela 5. Czas stażu pracy badanych po jakim wystąpiły dolegliwości bólowe kręgosłupa w zależności od okresu zatrudnienia.

\begin{tabular}{|c|c|c|c|c|c|c|}
\hline \multirow{3}{*}{$\begin{array}{c}\text { Czas stażu } \\
\text { pracy badanych }\end{array}$} & \multicolumn{6}{|c|}{ Okres zatrudnienia } \\
\hline & \multicolumn{2}{|c|}{ 1-10 lat } & \multicolumn{2}{|c|}{ 11-25 lat } & \multicolumn{2}{|c|}{26 i więcej lat } \\
\hline & liczba & $\%$ & liczba & $\%$ & liczba & $\%$ \\
\hline poniżej 5 lat & 17 & 89,5 & 37 & 77,1 & 10 & 30,3 \\
\hline 6-19 lat & 1 & 5,3 & 11 & 22,9 & 18 & 54,5 \\
\hline powyżej 25 lat & 0 & 0,0 & 0 & 0,0 & 5 & 15,2 \\
\hline nie wystąpiły & 1 & 5,3 & 0 & 0,0 & 0 & 0,0 \\
\hline Ogółem & 19 & 100,0 & 48 & 100,0 & 33 & 100,0 \\
\hline
\end{tabular}

Źródło: opracowanie własne

Najwięcej badanych z czasem zatrudnienia 1-10 lat wskazało, że dolegliwości bólowe kręgosłupa wystąpiły u nich już poniżej 5 lat stażu pracy - 89,5, najmniej wskazało, że 6-19 lat lub nie wystąpiły - po 5,3\%. Najwięcej badanych, których okres zatrudnienia wynosi 11-25 lat również odpowiedziało, że był to czas poniżej 5 lat stażu pracy - 77,1\%, pozostali wskazali, że 6-19 lat tj. 22,9\%. Najwięcej badanych z okresem zatrudnienia 26 i więcej lat wskazało, że po 6-19 latach stażu pracy $54,5 \%$, najmniej wskazało, że powyżej 25 lat $-15,2 \%$. 
W tabeli 6 przedstawiono okres stażu pracy po jakim wystąpiły dolegliwości bólowe kręgosłupa w grupach wykształcenia respondentów. Badani to absolwenci liceów medycznych, studium medycznych, a także studiów licencjackich i magisterskich na kierunku pielęgniarstwo.

Tabela 6. Okres stażu pracy po jakim wystąpiły dolegliwości bólowe kręgosłupa w grupach wykształcenia badanych.

\begin{tabular}{|c|c|c|c|c|c|c|c|c|}
\hline $\begin{array}{c}\text { Wykształ- } \\
\text { cenie }\end{array}$ & \multicolumn{2}{|c|}{$\begin{array}{c}\text { liceum } \\
\text { medyczne }\end{array}$} & \multicolumn{2}{c|}{$\begin{array}{c}\text { studium } \\
\text { medyczne }\end{array}$} & \multicolumn{2}{c|}{$\begin{array}{c}\text { licencjat } \\
\text { pielęgniar- } \\
\text { stwa }\end{array}$} & \multicolumn{2}{|c|}{$\begin{array}{c}\text { magister } \\
\text { pielęgniar- } \\
\text { stwa }\end{array}$} \\
\hline staż & liczba & \multicolumn{1}{|c|}{$\%$} & liczba & $\%$ & liczba & $\%$ & liczba & $\%$ \\
\hline $\begin{array}{c}\text { poniżej } \\
\text { 5 lat }\end{array}$ & 25 & 58,1 & 1 & 11,1 & 33 & 78,6 & 5 & 83,3 \\
\hline 6-19 lat & 17 & 39,5 & 4 & 44,4 & 8 & 19,0 & 1 & 16,7 \\
\hline $\begin{array}{c}\text { powyżej } \\
\text { 25 lat }\end{array}$ & 1 & 2,3 & 4 & 44,4 & 0 & 0,0 & 0 & 0,0 \\
\hline $\begin{array}{c}\text { nie } \\
\text { wystąpiły }\end{array}$ & 0 & 0,0 & 0 & 0,0 & 1 & 2,4 & 0 & 0,0 \\
\hline 0gółem & $\mathbf{4 3}$ & $\mathbf{1 0 0 , 0}$ & $\mathbf{9}$ & $\mathbf{1 0 0 , 0}$ & $\mathbf{4 2}$ & $\mathbf{1 0 0 , 0}$ & $\mathbf{6}$ & $\mathbf{1 0 0 , 0}$ \\
\hline
\end{tabular}

Źródło: opracowanie własne

Najwięcej absolwentów liceum medycznego wskazało, że dolegliwości bólowe kręgosłupa wystąpiły u nich już poniżej 5 lat stażu pracy - 58,1\%, a najmniej wskazało, że powyżej 25 lat - 2,3\%. Najwięcej osób, które ukończyły studium medyczne podało, że ból wystąpił po 6-19 latach oraz powyżej 25 lat zatrudnienia - po $44,4 \%$ a pozostali respondenci wskazali, że poniżej 5 lat pracy -11,1\%. Najwięcej licencjatów pielęgniarstwa wskazało, że dolegliwości pojawiły się poniżej 5 lat pracy- $78,6 \%$ a najmniej z nich podało, że nie wystąpiły one $-2,4 \%$. Najwięcej magistrów pielęgniarstwa potwierdziło dolegliwości bólowe, które pojawiły się poniżej 5 lat stażu pracy $-78,6 \%$ a pozostali badani, że 6-19 lat pracy - 16,7\%.

Ze względu na poziom istotności ( $\mathrm{p}<0,05)$, odnotowano statystycznie istotną różnię pomiędzy mieszkańcami miasta i wsi, dotyczącą wyników 
zagadnienia: w jaki sposób najczęściej radzi sobie respondenci z dolegliwościami bólowymi kręgosłupa? Tę zależność przedstawiono w tabeli 7.

Tabela 7. Najczęstsze sposoby radzenia sobie z dolegliwościami bólowymi kręgosłupa w grupach miejsca zamieszkania badanych.

\begin{tabular}{|c|r|r|r|r|}
\hline Miejsce zamieszkania & \multicolumn{2}{|c|}{ miasto } & \multicolumn{2}{c|}{ wieś } \\
\hline Sposób & liczba & \multicolumn{1}{c|}{$\%$} & \multicolumn{1}{c|}{ liczba } & \multicolumn{1}{c|}{$\%$} \\
\hline sięgam po leki przeciwbólowe & 12 & 44,4 & 56 & 76,7 \\
\hline $\begin{array}{c}\text { korzystam ze zwolnienia lekarskiego } \\
\text { korzystam z ambulatoryjnych zabiegów } \\
\text { rehabilitacyjnych }\end{array}$ & 7 & 29,6 & 9 & 12,3 \\
\hline korzystam z leczenia uzdrowiskowego & 0 & 25,9 & 4 & 5,5 \\
\hline inne (jakie?) ...... & 0 & 0,0 & 2 & 2,7 \\
\hline Ogółem & $\mathbf{2 7}$ & $\mathbf{1 0 0 , 0}$ & $\mathbf{7 3}$ & $\mathbf{1 0 0 , 0}$ \\
\hline
\end{tabular}

Źródło: opracowanie własne

W ramach radzenia sobie z dolegliwościami bólowymi kręgosłupa najwięcej mieszkańców miasta wskazało, że sięga po leki przeciwbólowe tj. 44,4\%. Najmniej respondentów podało, że korzysta z ambulatoryjnych zabiegów rehabilitacyjnych - 25,9\%.

Z kolei najwięcej mieszkańców wsi sięga w sytuacji bólu po leki przeciwbólowe 76,7\% Najmniej natomiast korzysta z leczenia uzdrowiskowego lub innych metod- po $2,7 \%$ badanych.

W tabeli 8 przedstawiono rozkład odpowiedzi badanych na pytanie, jak często stosują się do zasad ergonomii w miejscu pracy.

Tabela 8. Częstość stosowania zasad ergonomii w pracy z pacjentami.

\begin{tabular}{|c|r|r|}
\hline Częstość & liczba & \multicolumn{1}{c|}{ \% } \\
\hline zawsze & 59 & 59,0 \\
\hline często & 41 & 41,0 \\
\hline nigdy & 0 & 0,0 \\
\hline Ogółem & $\mathbf{1 0 0}$ & $\mathbf{1 0 0 , 0}$ \\
\hline
\end{tabular}

Źródło: opracowanie własne 
Najwięcej badanych wskazało, że zawsze stosuje zasady ergonomii w pracy z pacjentami - 59,0\%. Pozostali wskazali, że robią to często$41,0 \%$. Żaden z badanych nie wskazał odpowiedzi, że nigdy nie stosuje ergonomii podczas pracy z pacjentem.

W tabeli 9 przedstawiono rozkład odpowiedzi badanych na pytanie, jaką najczęściej przyjmują pozycję podczas przemieszczania pacjentów.

Tabela 9. Rozkład odpowiedzi badanych na pytanie, jaką najczęściej przyjmują pozycję podczas przemieszczania pacjentów.

\begin{tabular}{|c|c|c|}
\hline Pozycja & liczba & \% \\
\hline tułów wyprostowany, kolana ugięte & 24 & 24,0 \\
\hline tułów wyprostowany, kolana wyprostowane & 19 & 19,0 \\
\hline plecy okrągłe, kolana wyprostowane & 20 & 20,0 \\
\hline plecy okrągłe, kolana ugięte & 16 & 16,0 \\
\hline nie zwracam na to uwagi & 21 & 21,0 \\
\hline Ogółem & $\mathbf{1 0 0}$ & $\mathbf{1 0 0 , 0}$ \\
\hline
\end{tabular}

Źródło: opracowanie własne

Większość respondentów tj. 24\% przyznała, że przenosi chorych w pozycji na ugiętych kolanach z wyprostowanym tułowiem. Niewiele mniej badanych, bo $21 \%(\mathrm{n}=21)$ stwierdziło, że nie przywiązuje uwagi do pozycji przyjmowanej podczas przenoszenia chorych. Natomiast $20 \%$ wskazało na to, że w takich sytuacjach ma plecy okrągłe a kolana wyprostowane. W badaniu 19\% osób wypowiedziało się, że ich najczęstsza pozycja ciała podczas transferu chorych to tułów oraz kolana wyprostowane. Najmniej badanych tj. $16 \%$ podczas przenoszenia chorych zaokrągla plecy i ugina kolana.

\section{Dyskusja}

Praca wykonywana przez pielęgniarki może sprzyjać różnego rodzaju dolegliwościom ze strony układu mięśniowo-szkieletowego. Są to 
czynności wykonywane w pozycji zarówno stojącej, jak i siedzącej. Wiele z nich wykonują w nieergonomicznej pozycji ciała. Zdarza się, że nie są przestrzegane normy wagi podnoszonej przez pracowników, co dodatkowo sprzyja powstawaniu zespołów bólowych kręgosłupa w przyszłości. Pielęgniarki w ramach czynności zawodowych niejednokrotnie dźwigają pacjentów oraz sprzęt medyczny, przenoszą, podnoszą, pokonują bariery architektoniczne, pracują w systemie zmianowym, są bardzo obciążone stresem [10].

W przeprowadzonym przez nas badaniu wszyscy respondenci (100\%) doświadczają zespołów bólowych kręgosłupa. Zdecydowana większość (84\%) wskazuje, że jest to ból w okolicy lędźwiowej. Podobny wynik uzyskali Maciuk i wsp., gdzie aż 81\% respondentów odczuwało dolegliwości bólowe dolnego odcinka kręgosłupa [9]. W artykule opublikowanym przez Wolska i wsp., 60\% badanych deklarowało ból również w tej części ciała [11]. Z kolei Ovayolu i wsp. w przeprowadzonych badaniach stwierdzili, że 82,2\% pielęgniarek doświadcza bólu krzyża. U 53,1\% badanych ma on charakter przewlekły [12].

W przeprowadzonych badaniach zaobserwowano, że zespoły bólowe kręgosłupa w grupie badanych różnią się, w zależności od takich zmiennych socjodemograficznych jak: wiek, wykształcenie, staż pracy oraz miejsce zamieszkania. Natomiast nie zaobserwowano istotnych różnic w zależności od płci respondentów oraz ich formy zatrudnienia. W przypadku grup wiekowych 24-39 lat oraz 40-54 lata dolegliwości bólowe kręgosłupa pojawiły się u nich poniżej 5 lat stażu pracy, zaś prawie połowa badanych w wieku 55 i więcej lat odpowiedziała, że doświadczyły ich powyżej 25 lat stażu pracy. Wiek badanych pozostawał w istotnej statystycznie, średniej korelacji z okresem stażu, po jakim wystąpiły dolegliwości bólowe kręgosłupa $(\mathrm{p}<0,05)$. Wpływ wieku na poziom dolegliwości bólowych kręgosłupa przedstawiono w artykule opublikowanym przez Ovaylou i wsp., gdzie średnie oceny bólu były wyższe u pielęgniarek w wieku 34 lat i starszych [12].

Badani o stażu pracy 1-10 lat oraz 11-25 lat wskazywali, że dolegliwości bólowe kręgosłupa wystąpiły u nich już poniżej 5 lat stażu pracy. 
Te wyniki korespondują z badaniami przeprowadzonych przez Mekonnen, gdzie średni czas pracy po jakim wystąpiły pierwsze dolegliwości kręgosłupa był znacznie większy u pracowników ze stażem $<5$ lat [13]. Podobną zależność można zaobserwować $\mathrm{w}$ badaniach przeprowadzonych przez Juraszek, Hagner-Derengowską, Hoffmann, Kalisz oraz Żukowa [5]. Wywnioskowali oni, że średni czas po jakim badani zauważali dolegliwości bólowe ze strony kręgosłupa wynosił 8,04 lat.

Badani, którzy uzyskali tytuł magistra pielęgniarstwa, licencjata pielęgniarstwa oraz są absolwentami liceum medycznego najczęściej wskazywali, że dolegliwości bólowe kręgosłupa wystąpiły u nich poniżej 5 lat stażu pracy oraz 6-19 lat stażu pracy. Z kolei w badaniach przeprowadzonych przez Wolską i wsp. [11] odczuwanie bólu kręgosłupa częściej zgłaszały pielęgniarki z wykształceniem średnim niż z wykształceniem wyższym.

Badani bez względu na od miejsce zamieszkania jako sposób radzenia sobie z bólem stosowali leki przeciwbólowe. Podobne zachowanie zaobserwowano u respondentów badania przeprowadzonego przez Maciuk i Kajewską-Kułak oraz Klimaszewską[9].

W badaniach własnych zaobserwowano, że respondenci nie posiadali wiedzy na temat prawidłowej pozycji ciała podczas przemieszczania chorych. Świadczy o tym liczba zróżnicowanych odpowiedzi. Najwięcej respondentów wskazało, że przyjmuje pozycję z wyprostowanym tułowiem oraz ugiętymi kolanami - 24\%. Średnio $21,0 \%$ nie zwraca na to uwagi, $16 \%$ ma wówczas plecy okrągłe i kolana ugięte, zaś w badaniu opublikowanym przez Juraszek i wsp., najczęściej wskazywaną odpowiedzią była pozycja ciała charakteryzującą się wyprostowanym tułowiem i ugiętymi kolanami $(51,2 \%)$ [5].

W badaniach własnych działania na rzecz profilaktyki zespołów bólowych kręgosłupa różni się w zależności od zmiennych socjodemograficznych takich jak: wykształcenie oraz miejsce zamieszkania respondentów. Nie potwierdzono istotnych różnic w zależności od płci badanych, stażu pracy, wieku oraz formy zatrudnienia. Podobnie w publikacji Ovaylou i wsp. zaobserwowano, że pielęgniarki, które nigdy nie 
były edukowane w zakresie ergonomii w miejscu pracy, częściej doświadczały bólu (86,5\%) [12].

W badaniach własnych średnio $1 / 4$ mieszkańców miasta korzysta z ambulatoryjnych zabiegów rehabilitacyjnych. Z kolei mieszkańcy wsi w bardzo małej mierze korzystają z rozwiązań, które mogłyby zapobiec występowaniu zespołom kręgosłupa w przyszłości. Potwierdza tą zależność badanie Maciuk i wsp., gdzie 4\% badanych deklarowało, że korzysta z zabiegów rehabilitacyjnych [9].

\section{Wnioski}

1. Zespoły bólowe kręgosłupa $\mathrm{w}$ grupie badanych istotnie różnią się w zależności od takich zmiennych socjodemograficznych jak: wiek, staż pracy, wykształcenie, miejsce zamieszkania. Natomiast nie zaobserwowano istotnych różnic w zależności od płci respondentów oraz ich formy zatrudnienia.

2. Podejmowanie działań przez badanych w zakresie profilaktyki zespołów bólowych kręgosłupa istotnie różni się w zależności od zmiennych socjodemograficznych takich jak: wykształcenie oraz miejsce zamieszkania. Nie potwierdzono istotnych różnic w zależności od płci badanych, stażu pracy, wieku oraz formy zatrudnienia.

\section{Zalecenia dla praktyki pielęgniarskiej}

Zapobieganie chorobom kręgosłupa w grupie zawodowej pielęgniarek powinno obejmować przede wszystkim: właściwe zachowania w pracy, prawidłowe formy aktywności fizycznej, rekreacji i wypoczynku, utrwalenie prawidłowych wzorców ruchowych i dostosowanie warunków pracy.

\section{Bibliografia/ Bibliography:}

1. Szpala M., Skorupińska A., Kostorz K. Występowanie zespołów bólowych kręgosłupa - przyczyny i leczenie. Pomeranian Journal of Life Sciences. 2017;63:41-47.

2. Milanow J. Zespół bólowy kręgosłupa. Pediatr Med Rodz. 2014;10(3):253-264. 
3. Adamaszek M., Włoszczak-Szubzda A. Częstotliwość występowania bólu kręgosłupa u personelu medycznego. Aspekty zdrowia i choroby. 2018;1:133-151.

4. Piekarzewska M., Wieczorkowski R., Zajenkowska-Kozłowska A.: Stan zdrowia ludności Polski w 2014r. Wydawnictwo Zakład Wydawnictw Statystycznych. Warszawa 2016:67-69.

5. Juraszek K, Hagner-Derengowska M, Hoffmann M, Kalisz Z, Żukow W. Wpływ pracy zawodowej na występowanie zespołów bólowych kręgosłupa na przykładzie pielęgniarek województwa kujawsko - pomorskiego. Journal of Education, Health and Sport. 2016;6(8):504-521.

6. Kuriata E, Felińczak A, Grzebieluch J, Szachniewicz M. Czynniki szkodliwe oraz obciążenie pracą pielęgniarek zatrudnionych w szpitalu. Pielęgniarstwo i Zdrowie Publiczne 2011;1(3):269-273.

7. Waldman S. Atlas zespołów bólowych. Wydawnictwo Edra Urban \& Partner. Wrocław 2009:239-246.

8. Abolfotouh S.M., Mahmoud K., Faraj K., Moammer G., Elsayed A., Abolfotouh M. Prevalence, consequences and predictors of low back pain among nurses in a tertiary care setting. International Orthopaedics 2015;39: 2439-2449.

9. Maciuk M., Krajewska-Kułak E., Klimaszewska K. Samoocena występowania zespołów bólowych kręgosłupa u zawodowo czynnych pielęgniarek. Probl Hig Epidemiol. 2012;94(4):728-738.

10. Wyderka M., Niedzielska T. Ergonomia w pracy pielęgniarki. Pielęgniarstwo Polskie. 2016,2(60):165-169.

11. Wolska D., Filipska K., Haor B. Występowanie zespołów bólowych kręgosłupa lędźwiowo-krzyżowego wśród personelu pielęgniarskiego. Innowacje w Pielęgniarstwie i Naukach o Zdrowiu. 2018;2(3):55-69.

12. Ovayolu O., Ovayolu N., Genc Col-Araz N. Frequency and Severity of Low Back Pain in Nurses Working in Intensive Care Units and Influential Factors. Pak J Med Sci. 2014;30(1):70-76.

13. Mekonnen T. Work-Related Factors Associated with Low Back Pain Among Nurse Professionals in East and West Wollega Zones, Western Ethiopia, 2017: A Cross-Sectional Study. Pain and Therapy. 2019;8:239-247. 